\title{
Prediction of payment discipline using the Markov chain - case studies of Visegrad Four
}

\author{
Anna Siekelova \\ Faculty of Operation and Economics of Transport and \\ Communications, University of Zilina \\ Slovakia \\ anna.siekelova@fpedas.uniza.sk
}

\author{
Maria Kovacova \\ Faculty of Operation and Economics of Transport and \\ Communications, University of Zilina \\ Slovakia \\ maria.kovacova@fpedas.uniza.sk.
}

\section{George Lazaroiu}

Spiru Haret University, Bucharest

Romania

phd_lazaroin@yahoo.com

\section{Katarina Valaskova}

Faculty of Operation and Economics of Transport and

Communications, University of Zilina

Slovakia

katarina.valaskova@fpedas.uniza.sk

Abstract. This article responds to the current issue of declining payment discipline in the riskiest sector of the Visegrad Four. The aim of this article is to predict the future state of payment discipline in the selected sector of the Visegrad Four countries using the Markov chain. The turbulent market development has tested the financial stability of many businesses and their customers. The receivables and payment discipline of enterprises is an almost chronic problem, and not only of Slovak economy. The willingness of businesses to provide trade credit is declining. This paper defines the fundamental nature of receivables management. Within the overall receivables management process, the emphasis is primarily on assessing the creditworthiness of potential customers, which should be the basis for decision-making and more specifically - denial of trade credit. The authors identify the significant factors determining the payment 
discipline of enterprises in a selected sector of Visegrad Four countries. Subsequently, using the Markov chain based on past values $(20016,2017)$ of the chosen factors they predict the development of payment discipline in this sector.

Keywords: Markov chain, stochastic processes, cohort method, probability theory, payment discipline, Visegrad group

JEL Classification: G00, C10

\section{INTRODUCTION}

The issue of payment discipline is strongly interconnected with the competitiveness of companies (Kljucnikov et al., 2017). The payment discipline of enterprises reflects the phase of the economic cycle in which country's economy is currently located. Since the establishment of Slovak Republic, the payment discipline of Slovak enterprises has been associated with irregular payments, unreliability or unwillingness of customers to pay invoices properly and on time. We can also observe similar situation in the other countries of Visegrad Four. The financial crisis in 2007 has worsened the situation. This statement can be supported by the results of recent studies on the development of payment discipline. Every quarter the Business Alliance of Slovakia evaluates Slovak business environment through the Business Environment Index. According to entrepreneurs, the quality of business environment has deteriorated rapidly over the past 8 years. Entrepreneurs criticize lengthy litigation, bureaucracy or administrative burden, as well as reliability and payment discipline of their customers. (The results of the research conducted by Business Alliance of Slovakia). These problems are not solely Slovak ones. Worsened payment discipline was also recorded by the surveys carried out at transnational level. The European Payment Report conducted by Intrum Justicia is based on the annual survey and data from thousands of companies across Europe to gain insight into the payment behavior and financial health of European businesses. Mikael Ericson, CEO and President at Intrum Justitia, states: "While I am pleased to note the businesses of Europe have a somewhat brighter outlook for the future in general, it is alarming that the payment culture is going in the wrong direction. The economic environment is being severely affected by some businesses pushing contractual terms for sub-suppliers towards 90 days or longer and deliberately paying later than agreed. We need new initiatives to establish a radically new culture of prompt payments". Many companies used the invoice payment as a short-term loan option in times of crisis. We can consider the topic of our contribution as current.

The contribution is focused on the issue of payment discipline in the Visegrad Four. Our aim is identification of statistically significant factors determining the solvency in companies of the Visegrad Four. Subsequently, we try to determine the development of payment discipline by using Markov chain.

Providing trade credits is a common practice in business so as the existence of trade receivables. Many trade receivables are not paid properly and on time. Such a receivable can contribute to significant liquidity problems in a company that has provided a trade credit. This phenomenon is known as secondary insolvency. Secondary insolvency may negatively affect other entities in mutual suppliercustomer relations with a company. In our previous research work, we dealt with receivable management as an effective tool in preventing liquidity problems that are the result of providing trade credits. Receivable management contains three main parts:

- prevention,

- monitoring,

- recovery (if necessary). 
Many authors (Culkova et al., 2015; Valaskova \& Gregova, 2017; Kozubikova et al., 2017) claim that prevention is the most important part. We do not state that the other parts are not important though. But we agree with the opinion that if the company consistently approaches the decision about providing or not providing a trade credit, which is being implemented precisely in the context of prevention, the risk of unpaid invoices will reduce. By monitoring receivables, the enterprise can only reduce the risk of unpaid invoices due to administrative inefficiency. During the monitoring phase, late detection that the business partner does not have a presumption to pay the invoice properly and on time can already threaten financial stability of the company. At this stage it is no longer possible to reassess the provision of a trade credit. The recovery phase is particularly important at a time when the company has been in a situation where its receivables are not paid. On the other hand, the risk of a business getting into this situation could be reduced by a proactive approach to managing receivables at the prevention phase. A proactive approach means that we deal with a receivables before it arises. The nature of the first part is to avoid providing trade credits to customers who will not be able to fulfill commitment properly and on time. Within this prevention, the company answers the question whether it will provide a trade credit and under what conditions (a trade credit amount, the maturity etc.) or providing of a trade credit will be refused to an individual business partner. The answer is particularly determined by the analysis of potential business partner's financial condition and prediction of its development. Creditworthiness of applicants for bank credit is verified by the bank through their own rating system (Cipovova \& Belas, 2012). The calculation algorithm depends on a particular bank. Banks, when assessing clients' creditworthiness, also have a lot of information that cannot be obtained for a business in many cases (Abdou et al., 2016.) There are some universal mathematical and statistical methods that can be used by businesses in such cases (Cygler \& Sroka, 2017; Bracinikova \& Matusinska, 2017; Moravcikova et al., 2017).

Our contribution deals with predicting the development of payment discipline in the riskiest sector of the Visegrad Four using a statistical method tknown as the Markov chain. Our intention is to determine significant indicators of payment discipline while assessing the payment discipline in the Visegrad Four and at the end, we would like to predict their development in the future. Markov chain is widely used in various research studies, primarily those on banking issues. Credit risk management plays an important role in current banking. In managing credit risks, it is important to correctly estimate the likelihood that a client's creditworthy behaviour may change. We have decided to use this method to measure the insolvency risk of potential V4 trading partners with the focus on trade credits provision. We did not use only one statistical method - Markov chain, we also used the Pearson correlation coefficient, we tested the significance of the correlation coefficient to confirm the hypothesis and Grubbs' test for outliers was also used because we had a large sample of businesses, in which extreme values of indicators can distort the results of our research. Descriptions of the methods used and of the calculations are given below.

\section{LITERATURE REVIEW}

Relationship Markov processes are named after Andrey Andreyevich Markov. It was the Russian mathematician who dealt with stochastic processes in the early 20th century. He published his first paper on the topic in 1906. Markov studied an extension of independent random sequences which is motivated by a disagreement with Pavel Nekrasov. Pavel Nekrasov claimed independence was necessary for the weak law of large numbers to hold. (Seneta, 1996) In his first paper Markov showed that under certain conditions the average outcomes of the Markov chain would converge to a fixed vector of values, so proving a weak law of large numbers without the independence assumption, (Chajdiak et al., 1997) which had been commonly regarded as a requirement for such mathematical laws to hold. Markov later used 
Markov chains to study the distribution of vowels in Eugene Onegin, written by Alexander Pushkin, and proved a central limit theorem for such chains. (Vojtovic, 2016; Nipun et al., 2018)

A primary subject of his research later became known as Markov chains and Markov processes. Many probability studies deal with independent trials processes. (Grinstead \& Snell, 1997) If a sequence of chance experiments forms an independent trials process, the possible outcomes for each experiment are the same and occur with the same probability. Modern probability theory studies chance processes for which the knowledge of previous outcomes influences predictions for future experiments. (Spahn, 2017; Nica \& Catalina-Oana, 2017) In the theory of probability Markov chain is one of the separate chapters in the stochastic processes. In the Markov process, the result of the current experiment can affect the result of the experiment in the future. Stochastic process $\left\{X_{t}, t \in T\right\}$ may be identified as Markov process if it satisfies Markov property. Markov property means that the probability distribution of future states $t>s$ depends only upon the present state $s$, not on the sequence of events that preceded it. Markov process is also known as "memorylessness" process. Markov chain can be described as follows. We have a set of states, $S=\left\{s_{1}, s_{2}, s_{3}, \ldots s_{n}\right\}$. The process starts in one of these states and moves successively from one state to another. Each move is called a step. If the chain is currently in state $s_{i}$, then it moves to state $s_{j}$ at the next step with a probability denoted by $p_{i j}$, and this probability does not depend upon which states the chain was in before the current state (Markov property).

Transition probability from state $i$ to state $j$ can be written as follows. (Seneta, 1996)

$$
p_{i j}(n, n+m)=P\left(X_{n+m}=j \mid X_{n}=i\right)
$$

Transition probabilities can be arranged in a square matrix $P=\left\{p_{i j}, i, j \in S\right\}$, also known as a transition matrix. For every $i, j \in S$ applies that $p_{i j} \geq 0$ and also that $\sum_{j \in S} p_{i j}=1$, it means that the sum of the entries for each row is 1 .

There is also a need to specify the space and time parameter. The following table 1 shows an overview of Markov processes for different levels of generality and state space for discrete and continuous time.

Table 1

\begin{tabular}{|c|c|c|}
\hline & COUNTABLE STATE SPACE & CONTINUOUS OR GENERAL \\
STATE SPACE
\end{tabular}

Source: Seneta, 1996

Below we deal with homogeneous Markov process with the discrete state in which random variables take only integer values.

\section{METHODOLOGY}

The basic prerequisite for this research was the study of domestic and foreign literature, which deals with the issue of receivable management. As mentioned above many authors claim that the key part of receivable management is it's the first part - prevention. Receivable management is still considered as an 
intuitive process by many businesses. Many companies do not deal with its trade receivables until they are not paid properly and on time. Like other authors (Gorczynska, 2011; Kollar et al., 2015; Kralovic \& Vlachynsky, 2006; Soucek \& Kubickova, 2011; Wells, 2004), we do not agree with this attitude. Thorough dealing with trade receivable before it becomes is the basis for the proactive management of the company's receivables. "Dealing with trade receivable before it becomes" is based on the fact that the company has the possibility to refuse to provide a trade credit. An enterprise's decision about providing a trade credit should take into account its own financial stability as well as the financial stability of a potential business partner. In the beginning, we had to find out statistically significant indicators that determine payment discipline of the company. In order to assess the ability of an enterprise to repay a trade credit, it is recommended (Michalski, 2013; Salek, 2005; Paul \& Devi, 2012; Sadaf et al., 2018; Olah et al., 2018) to monitor in particular its liquidity. The existence of free funds in an enterprise is a prerequisite for repayment of the obligation. In the research, we have solved which indicators have an impact on the liquidity indicator. In previous research works authors (Svabova \& Durica, 2016; Weissova et al., 2015; Weissova \& Gregova, 2016; Voznakova, 2004) recommend to focus on the indebtedness of potential business partner, the average maturity of its commitments, as well as profitability indicators. (Kliestik et al., 2018; Kliestikova et. al., 2017; Balcerzak et. al., 2017) Based on the above, we decided to examine the existence of a statistically significant relationship between quick ratio, which we have identified as the main determinant of a trade credit repayment, and selected indicators, as followed:

- Quick Ratio,

- Total Debt Ratio,

- Credit Indebtedness,

- Days Sales Outstanding,

- Days Payable Outstanding,

- Return on Assets,

- Return on Sales,

- Indicator characterizing the imminent decline of the company.

The following Table 2 shows the methods of calculation that was used.

Table 2

\begin{tabular}{|c|c|}
\hline SELECTED FINANCIAL INDICATOR & CALCULATION \\
\hline Quick Ratio & Financial Accounts + Short - term Receivables \\
\hline Total Debt ratio & $\frac{\text { Foreign Resources }+ \text { Accrued Liabilities }}{\text { Short }- \text { term } \text { Foreign Resources }+ \text { Short }- \text { term Accrued Lialies }}$ \\
\hline Credit Indebtness & $\frac{\text { Credits }+ \text { Borrots }}{\text { Total Assets }}$ \\
\hline Days Sales Outstanding & $\frac{\text { Trade Receivables }}{\text { Revenues from Sales of Goods, Products and Services }}$ \\
\hline Days Payable Outstanding & $\frac{\text { Trade Payable }}{\text { Total Cost }}$ \\
\hline Return on Assets & $\frac{\text { EBIT DA }}{\text { Total Assets }}$ \\
\hline Return on Sales & $\frac{\text { EBIT DA }}{\text { Sales }}$ \\
\hline $\begin{array}{c}\text { Indicator characterizing the imminent decline } \\
\text { of the company }\end{array}$ & $\frac{\text { Equity }}{\text { Liabilities }}$ \\
\hline
\end{tabular}

Source: authors based on Levy \& Sarnat, 1998 
Our database is made up of 950 small and medium-sized companies from each country of Visegrad Four which are doing business in the construction sector, 3,800 companies in total. Our research is focused on V4 countries. For the purposes of our research, it was necessary to obtain data from the financial statements of V4 countries. Last year our department gained access to the Amadeus database created and produced by Bureau van Dijk A Moody's Analytics Company. So far, we have data on European businesses for 2016 to 2017. In the future, after obtaining the necessary data, we are planning to extend our research for years to come. Therefore, in this research we have been working with data from the financial statements of these companies for the years 2016 - 2017. As was mentioned above, research manuscripts reporting large datasets that are deposited in Amadeus. Amadeus contains comprehensive information on around 21 million companies across Europe. You can use it to research individual companies, search for companies with specific profiles and for analysis. We focused only on companies with private domestic ownership structure. At the beginning, we calculated selected indicators. Due to the size of our sample following table 3 shows only a part of the calculation.

Table 3

\begin{tabular}{|c|c|c|c|c|c|c|c|}
\hline $\begin{array}{c}\text { Quick Ratio } \\
\text { [coef.] }\end{array}$ & $\begin{array}{c}\text { Total Debt } \\
\text { Ratio } \\
\text { [coef.] }\end{array}$ & $\begin{array}{c}\text { Credit } \\
\text { Indebtedne } \\
\text { ss } \\
\text { [coef.] }\end{array}$ & $\begin{array}{c}\text { Days Sales } \\
\text { Outstandin } \\
\mathbf{g} \\
\text { [days] }\end{array}$ & $\begin{array}{c}\text { Days } \\
\text { Payable } \\
\text { Outstandin } \\
\text { g [days] }\end{array}$ & $\begin{array}{c}\text { Return on } \\
\text { Assets } \\
\text { [coef.] }\end{array}$ & $\begin{array}{c}\text { Return on } \\
\text { Sales [coef.] }\end{array}$ & $\begin{array}{c}\text { Indicator } \\
\text { characterizi } \\
\text { ng the } \\
\text { imminent } \\
\text { decline of } \\
\text { of } \\
\text { company } \\
\text { [coef.] }\end{array}$ \\
\hline 1.07 & 0.88 & 0.70 & 168.04 & 90.82 & 0.05 & 0.02 & 0.42 \\
\hline 0.61 & 0.80 & 0.63 & 17.00 & 42.36 & 0.08 & -0.01 & 0.60 \\
\hline$\ldots$ & $\ldots$ & $\ldots$ & $\ldots$ & $\ldots$ & $\ldots$ & $\ldots$ & $\ldots$ \\
\hline
\end{tabular}

Source: authors

The values of some indicators showed a striking deviation from others. Such values are called outliers, and it is recommended to exclude them from the database because it can falsify the results of other analyses. For this reason, we decided to proceed to the exclusion of extreme values. Results from a survey conducted within database without extreme values - "outliers" can be considered more relevant. As mentioned above the two-sided version of Grubbs' test was used for the identification of outliers. This test detects outliers from normal distributions. Grubbs' test is defined for the hypothesis: (Grubbs, 1950)

- $\mathrm{H}_{0}$ : There are no outliers in the data set.

- $\mathrm{H}_{a}$ : There is at least one outlier in the data set.

The significance level was set at $\alpha=0.05$. Grubb's test results for each indicators are as follows. Tables 4 show the results of the test. 


\begin{tabular}{|c|c|c|c|c|c|c|c|c|}
\hline & Quick Ratio & $\begin{array}{c}\text { Total Debt } \\
\text { Ratio }\end{array}$ & $\begin{array}{c}\text { Credit } \\
\text { Indebtedness }\end{array}$ & $\begin{array}{c}\text { Days Sales } \\
\text { Outstanding }\end{array}$ & $\begin{array}{l}\text { Days Payable } \\
\text { Outstanding }\end{array}$ & $\begin{array}{l}\text { Return on } \\
\text { Assets }\end{array}$ & $\begin{array}{l}\text { Return on } \\
\text { Sales }\end{array}$ & $\begin{array}{c}\text { Indicator } \\
\text { characterizin } \\
\mathrm{g} \text { the } \\
\text { imminent } \\
\text { decline of } \\
\text { the company }\end{array}$ \\
\hline $\begin{array}{l}\text { OBSERVED } \\
\text { VALUE }\end{array}$ & 65.8 & 66.9 & 52.98 & 67.8 & 59.5 & 64.5 & 66.7 & 58.4 \\
\hline $\begin{array}{l}\text { CRITICAL } \\
\text { VALUE }\end{array}$ & 4.6 & 4.6 & 4.6 & 4.6 & 4.6 & 4.6 & 4.6 & 4.6 \\
\hline P - VALUE & $<0.0001$ & $<0.0001$ & $<0.0001$ & $<0.0001$ & $<00001$ & $<0.0001$ & $<0.0001$ & $<0.0001$ \\
\hline
\end{tabular}

Source: authors

In all cases, the zero hypothesis is accepted. Consequently, we have excluded values that have been marked as "outliers". There are 2,835 businesses in our database.

The next step is the determination of statistically significant indicators of payment discipline which is determined by quick ratio indicators. So we dealt with the issue of whether the change of the selected indicators really affects the change in the liquidity of the company. The next hypothesis was defined.

- H 1: There is a statically significant relation between quick ratio indicator determining payment discipline of the company and total debt ratio indicator.

- H 2: There is a statically significant relation between quick ratio indicator determining payment discipline of company and credit indebtedness indicator.

- H 3: There is a statically significant relation between quick ratio indicator determining payment discipline of company and days sales outstanding indicator.

- H 4: There is a statically significant relation between quick ratio indicator determining payment discipline of company and days payable outstanding indicator.

- H 5: There is a statically significant relation between quick ratio indicator determining payment discipline of the company and return on assets indicator.

- H 6: There is a statically significant relation between quick ratio indicator determining payment discipline of the company and return on sales indicator.

- H 7: There is a statically significant relation between quick ratio indicator determining payment discipline of the company and an indicator characterizing the imminent decline of the company.

To confirm the existence of statistical dependence we tested the significance of the correlation coefficient. The test statistic has a Student t-distribution with $(n-2)$ degrees of freedom.

$$
T=r \cdot \sqrt{\frac{n-2}{1-r^{2}}}
$$

Where:

$n$ - sample size,

$r$ - Pearson correlation coefficient.

If $T$ is less than the critical value from the table of Student distribution at alpha (we set alpha at 0.05) level with $(n-2)$ degrees of freedom, we can assume that there is a statistically significant relationship between the surveyed indicators (Rimarcik, 2007). 
The strength of this dependence is expressed by Pearson correlation coefficient. In interpreting the results Cohen's interpretive of Pearson correlation coefficient was used as follow: $0<|r| \leq 0.1$ trivial dependence, $0.1 \leq|r| \leq 0.3$ small dependence, $0.3<|r| \leq 0.5$ moderate dependence, $0.5<|r| \leq 0.7$ large dependence, $0.7<|r| \leq 0.9$ very large dependence, $0.9<|r| \leq 1$ nearly perfect correlation. (Cohen, 2003)

The last part of our contribution consists of the use of the Markov chain to predict the development of payment discipline in the selected sector, which history and theoretical background are mentioned above.

\section{EMPIRICAL RESULTS AND DISCUSSION}

\subsection{Pearson correlation coefficient}

As mentioned above we measured the linear correlation between quick ratio indicator determining payment discipline and other selected indicators of financial economic analysis using Pearson correlation coefficient. Data from 2016 were used. Table 5 shows the results of the Pearson correlation coefficient.

Table 5

\begin{tabular}{|c|c|c|}
\hline SELECTED FINANCIAL INDICATOR & $\begin{array}{c}\text { Pearson correlation } \\
\text { coefficient }\end{array}$ & Interpretation by Cohen \\
\hline Total Debt ratio & -0.302 & negative small linear correlation \\
\hline Credit Indebtedness & -0.491 & negative moderate linear correlation \\
\hline Days Sales Outstanding & -0.593 & negative large positive correlation \\
\hline Days Payable Outstanding & 0.042 & positive trivial linear correlation \\
\hline Return on Assets & 0.284 & positive small linear correlation \\
\hline Return on Sales & 0.423 & positive moderate linear correlation \\
\hline $\begin{array}{c}\text { Indicator characterizing the imminent decline } \\
\text { of the company }\end{array}$ & 0.782 & positive very large correlation \\
\hline
\end{tabular}

Source: authors, processed in the program XLSTAT

As we can see the highest dependence was measured between quick ratio indicator and indicator characterizing the imminent decline of the company - 0.782 - positive very large correlation. "Positive" means that an increase of one indicator is connected with an increase of the other. It will also apply in case of a decrease. A decrease of one indicator is connected with a decrease of the other. A positive correlation is also between quick ratio indicator and these indicators: days payable outstanding, return on assets and return on sales. On the other hand, negative linear correlation was measured between quick ratio indicator and these indicators: total debt ratio indicator, credit indebtedness and days sales outstanding. "Negative" means that an increase of one indicator is connected with a decrease of the other and vice versa.

\subsection{Testing hypothesis}

Subsequently, we focused on the testing hypothesis. Measured correlation by Pearson correlation coefficient does not have to mean that there is confirmed the statistical relation between indicators. The results of Pearson correlation coefficient may refer values in our dataset. To confirm the existence of statistical dependence we tested the significance of the correlation coefficient. The whole procedure is 
statistically described above. We tested seven defined hypothesis. The results of this test are shown in Table 6.

Table 6

\begin{tabular}{|c|c|c|c|}
\hline HYPOTHESIS & T-VALUE & $\begin{array}{c}\text { CRITICAL } \\
\text { VALUE } \\
\text { (Rimarcik, 2007) } \\
\boldsymbol{t}_{\boldsymbol{\alpha}}(\boldsymbol{n}-\mathbf{2})\end{array}$ & RESULT \\
\hline $\begin{array}{c}\text { There is a statically significant relation between quick ratio } \\
\text { indicator determining payment discipline of the company } \\
\text { and total debt ratio indicator. }\end{array}$ & 16.87 & 1.645 & $\begin{array}{c}\text { The statically significant } \\
\text { relation is confirmed }\end{array}$ \\
\hline $\begin{array}{c}\text { There is a statically significant relation between quick ratio } \\
\text { indicator determining payment discipline of company and } \\
\text { credit indebtedness indicator. }\end{array}$ & 20.64 & 1.645 & $\begin{array}{c}\text { The statically significant } \\
\text { relation is confirmed }\end{array}$ \\
\hline $\begin{array}{c}\text { There is a statically significant relation between quick ratio } \\
\text { indicator determining payment discipline of company and } \\
\text { days sales outstanding indicator. }\end{array}$ & 24.34 & 1.645 & $\begin{array}{c}\text { The statically significant } \\
\text { relation is confirmed }\end{array}$ \\
\hline $\begin{array}{c}\text { There is a statically significant relation between quick ratio } \\
\text { indicator determining payment discipline of company and } \\
\text { days payable outstanding indicator. }\end{array}$ & 6.98 & 1.645 & $\begin{array}{c}\text { The statically significant } \\
\text { relation is confirmed }\end{array}$ \\
\hline $\begin{array}{c}\text { There is a statically significant relation between quick ratio } \\
\text { indicator determining payment discipline of the company } \\
\text { and return on assets indicator. }\end{array}$ & 15.33 & 1.645 & $\begin{array}{c}\text { The statically significant } \\
\text { relation is confirmed }\end{array}$ \\
\hline $\begin{array}{c}\text { There is a statically significant relation between quick ratio } \\
\text { indicator determining payment discipline of the company } \\
\text { and return on sales indicator. }\end{array}$ & 16.85 & 1.645 & $\begin{array}{c}\text { The statically significant } \\
\text { relation is confirmed }\end{array}$ \\
\hline $\begin{array}{c}\text { There is a statically significant relation between quick ratio } \\
\text { indicator determining payment discipline of the company } \\
\text { and an indicator characterizing the imminent decline of the } \\
\text { company. }\end{array}$ & 38.56 & 1.645 & $\begin{array}{c}\text { The statically significant } \\
\text { relation is confirmed }\end{array}$ \\
\hline
\end{tabular}

Source: authors, processed in the program XLSTAT

We chose selected indicators based on domestic and foreign studies deal with assessing payment ability. We focused on the indicators that are recommended to follow in the process of decision making about proving trade credit. As was mentioned above these indicators were chosen based on not only domestic but also on many foreign studies. Therefore at the beginning we focused on proving statement that these indicators are really statistically significant and have impact on payment discipline based on our data. In all cases $T \geq t_{\alpha}(n-2)$. Based on the results all hypothesis can be confirmed. Therefore, we have proved that the selected indicators are statistically significant and have an impact on the quick ratio indicator and therefore it is worthwhile to assess them when assessing the company's ability to pay.

\subsection{Assessment of payment discipline - rating model}

As mentioned above we have proved that all tested indicators have a ignificant impact on the payment discipline, therefore, all of them should be considerate in the process of assessing payment discipline. Based on this rating model to assess payment discipline was defined.

Following table 7 shows the recommended values of indicators and also its the median value that companies of our database reached 2016 and 2017. 
Table 7

\begin{tabular}{|c|c|c|c|}
\hline SELECTED FINANCIAL INDICATOR & $\begin{array}{c}\text { RECOMMENDED } \\
\text { VALUE }\end{array}$ & $\begin{array}{c}\text { MEDIAN VALUE } \\
\mathbf{2 0 1 4}\end{array}$ & $\begin{array}{c}\text { MEDIAN VALUE } \\
\mathbf{2 0 1 5}\end{array}$ \\
\hline Quick Ratio & More than 1 & 1.62 & 1.80 \\
\hline Total Debt ratio & $50-70 \%$ & $91.02 \%$ & $90.76 \%$ \\
\hline Credit Indebtedness & $20-30 \%$ & $8.12 \%$ & $9.23 \%$ \\
\hline Days Sales Outstanding & 60 days & 188 days & 185 days \\
\hline Days Payable Outstanding & 60 days & 210 days & $-0.7 \%$ \\
\hline Return on Assets & More than $15 \%$ & $-0.56 \%$ & $-12.3 \%$ \\
\hline Return on Sales & More than $10 \%$ & -9.22 & 1.34 \\
\hline $\begin{array}{c}\text { Indicator characterizing the imminent decline } \\
\text { of the company }\end{array}$ & More than 0,04 & 1.24 & days \\
\hline
\end{tabular}

Source: authors, based on Kestens et al. 2012; Kristofik, 1988; Weissova \& Misankova, 2015

Based on the recommended values and median values we set a rating scale as table 8 shows.

Table 8

\begin{tabular}{|c|c|c|c|c|c|}
\hline SELECTED FINANCIAL INDICATOR & $\mathbf{- 1 0}$ & $\mathbf{- 5}$ & $\mathbf{0}$ & $\mathbf{5}$ & $\mathbf{1 0}$ \\
\hline Quick Ratio & $\begin{array}{c}\text { Less than } \\
0.5\end{array}$ & $0.5-0.8$ & $0.8-1.2$ & $1.2-1.5$ & $\begin{array}{c}\text { More than } \\
1.5\end{array}$ \\
\hline Total Debt ratio & $\begin{array}{c}\text { More than } \\
85 \%\end{array}$ & $75-85 \%$ & $65-75 \%$ & $55-65 \%$ & $\begin{array}{c}\text { Less than } \\
55 \%\end{array}$ \\
\hline Credit Indebtness & $\begin{array}{c}\text { More than } \\
40 \%\end{array}$ & $30-40 \%$ & $20-30 \%$ & $10-20 \%$ & $\begin{array}{c}\text { Less than } \\
10 \%\end{array}$ \\
\hline Days Sales Outstanding & $\begin{array}{c}\text { More than } \\
120 \text { days }\end{array}$ & $\begin{array}{c}100-120 \\
\text { days }\end{array}$ & $\begin{array}{c}80-100 \\
\text { days }\end{array}$ & $60-80$ days & $\begin{array}{c}\text { Less than } 60 \\
\text { days }\end{array}$ \\
\hline Days Payable Outstanding & $\begin{array}{c}\text { More than } \\
120 \text { days }\end{array}$ & $\begin{array}{c}100-120 \\
\text { days }\end{array}$ & $\begin{array}{c}80-100 \\
\text { days }\end{array}$ & $60-80$ days & $\begin{array}{c}\text { Less than } 60 \\
\text { days }\end{array}$ \\
\hline Return on Assets & $\begin{array}{c}\text { Less than } \\
-2 \%\end{array}$ & $-2-2 \%$ & $2-6 \%$ & $6-10 \%$ & $\begin{array}{c}\text { More than } \\
10 \%\end{array}$ \\
\hline Return on Sales & $\begin{array}{c}\text { Less than } \\
-2 \%\end{array}$ & $-2-2 \%$ & $2-6 \%$ & $6-10 \%$ & $\begin{array}{c}\text { More than } \\
10 \%\end{array}$ \\
\hline Indicator characterizing the imminent decline of \\
the company & $0-0.04$ & $0.04-0.06$ & $0.06-0.08$ & $0.08-0.10$ & $\begin{array}{c}\text { More than } \\
0.10\end{array}$ \\
\hline
\end{tabular}

Source: authors

Selected indicators were calculated within each company of our database. Based on the results company could obtain in the individual indicators from -10 to 10 points. On the basis of the sum of points in the individual indicators, we ranked company into one of the rating groups as following table 9 shows. Enterprise with negative equity was automatically included in the 6th rating category. Based on the of the Act no. 7/2005 Coll. on bankruptcy and restructuring, as amended. It is a company in decline which is subject to special provisions. 
Table 9

\begin{tabular}{|c|c|c|c|}
\hline & SUM OF POINTS & $\begin{array}{c}\text { NUMBER OF } \\
\text { COMPANIES 2016 }\end{array}$ & $\begin{array}{c}\text { NUMBER OF } \\
\text { COMPANIES 2017 }\end{array}$ \\
\hline 1ST RATING GROUP & More than 60 & 369 & 423 \\
\hline 2ND RATING GROUP & $40-60$ & 414 & 456 \\
\hline 3RD RATING GROUP & $0-40$ & 915 & 503 \\
\hline 4TH RATING GROUP & $-40-0$ & 528 & 364 \\
\hline 5TH RATING GROUP & $-80-(-40)$ & 54 & 513 \\
\hline COMPANY IN DECLINE & Negative equity & 555 & \\
\hline
\end{tabular}

Source: authors

Rating groups are listed according to the degree of financial health. Applies that companies in the first rating group have the best financial health.

\subsection{Prediction payment discipline}

The transition between the states of the Markov chain ("a step") is in this case represented by the transition between rating groups. We dealt with discrete-time Markov chain because we considered belonging to a rating group at given intervals of one year. There are several approaches to determining the transition matrix that shows transition probabilities. For our needs, we selected a cohort method, which assumes discrete-time Markov chains and its homogeneity. It is based on the calculation of the relative transitions between rating categories at the beginning and end of the period. Cohort method is based on a comparison of the number of companies to which their rating changed from $i$ to $j$ between the beginning and the end of the reporting period (i.e. between 2016 and 2017) with the number of customers in rating group $i$ at the beginning of the period (2014). The resulting transition matrix is shown below (Table 10).

Table 10

\begin{tabular}{|c|c|c|c|c|c|c|}
\hline & $\begin{array}{c}\text { 1ST RATING } \\
\text { GROUP }\end{array}$ & $\begin{array}{c}\text { 2ND } \\
\text { RATING } \\
\text { GROUP }\end{array}$ & $\begin{array}{c}\text { 3RD } \\
\text { RATING } \\
\text { GROUP }\end{array}$ & $\begin{array}{c}\text { 4TH } \\
\text { RATING } \\
\text { GROUP }\end{array}$ & $\begin{array}{c}\text { 5TH } \\
\text { RATING } \\
\text { GROUP }\end{array}$ & $\begin{array}{c}\text { COMPANY } \\
\text { IN } \\
\text { DECLINE }\end{array}$ \\
\hline $\begin{array}{c}\text { 1ST RATING } \\
\text { GROUP }\end{array}$ & $\mathbf{5 6 . 9 1 \%}$ & $25.20 \%$ & $13.82 \%$ & $3.25 \%$ & $0.00 \%$ & $0.81 \%$ \\
\hline $\begin{array}{c}\text { 2ND RATING } \\
\text { GROUP }\end{array}$ & $28.99 \%$ & $29.71 \%$ & $\mathbf{3 1 . 8 8} \%$ & $6.52 \%$ & $0.72 \%$ & $2.17 \%$ \\
\hline $\begin{array}{c}\text { 3RD RATING } \\
\text { GROUP }\end{array}$ & $8.52 \%$ & $19.34 \%$ & $\mathbf{5 1 . 4 8} \%$ & $16.39 \%$ & $0.33 \%$ & $3.93 \%$ \\
\hline $\begin{array}{c}\text { 4TH RATING } \\
\text { GROUP }\end{array}$ & $0.00 \%$ & $7.95 \%$ & $35.80 \%$ & $46.59 \%$ & $2.84 \%$ & $6.82 \%$ \\
\hline $\begin{array}{c}\text { 5TH RATING } \\
\text { GROUP }\end{array}$ & $0.00 \%$ & $5.56 \%$ & $16.67 \%$ & $\mathbf{5 0 . 0 0 \%}$ & $16.67 \%$ & $11.11 \%$ \\
\hline $\begin{array}{c}\text { COMPANY IN } \\
\text { DECLINE }\end{array}$ & $2.70 \%$ & $3.24 \%$ & $9.19 \%$ & $7.57 \%$ & $1.08 \%$ & $\mathbf{7 6 . 2 2 \%}$ \\
\hline
\end{tabular}

Source: authors

Transition matrix informs about the transitions between rating groups between 2016 and 2017. Rows represent 2016, while columns represent 2017. There is a 57\% probability that enterprises from the first rating group will maintain the same level of financial ability to pay its debts. But also there is still $25.20 \%$ 
probability that these companies will move to 2 nd rating group. Within the next rating category, the results are not so clear. There is a probability of slight improvement (28.99\% a step to 1 st rating group) but also slight deterioration (31.88\% a step to 3rd rating group) of financial ability to pay its debts in the future. Companies included in the 3rd rating group most likely (almost 52\%) remain in this. There is also $50 \%$ probability for companies form the 5 th that they get into the 4th rating group in the future period. Based on the results it can be stated that the payment discipline of businesses in the construction sector will most likely not significantly change.

\section{CONCLUSION}

The aim of the article was to predict the future state of payment discipline in the selected sector of the Visegrad Four countries using the Markov chain. Assessing payment discipline is a very important part of effective receivable management mainly in the condition of the current business environment. Providing trade credits is common. Issuing an invoice is a daily part of doing business. But many businesses underestimate the risk they face. An unpaid invoice can significantly threaten the financial stability of a business lending company. The largest share of unpaid invoices in 2018 was in the construction sector. At the same time, the share of small and medium-sized enterprises that have ceased their activities has increased significantly. Based on the result of research we can state that willingness of providing trade credits has decreased. (Intrum Justitia, 2018) These reasons were significant for focusing on the future development of payment discipline in the construction sector for the SME sector.

The results of our research are based on data from the accounting statements of V4 countries. We focused on the market of V4 that can be marked as emerging markets. We have been working with data for 2016, 2017. We have obtained this data from the Amadeus database, as was mentioned above. It is a database that we only accessed last year. In the future, we would like to extend our research for years to gain a timeline of data, and we would like to apply other statistical methods (Granger causality test, duration method or Aalen Johansen estimate) that could lead to interesting findings.

At the beginning, we excluded from our database companies whose calculated indicators showed significantly deviations from others. These values are referred to as "outliers". It is recommended to exclude them from the database because it can falsify the results of other analyses. For this reason, we decided to proceed to the exclusion of extreme values using two-sided version of Grubbs' test.

There are many studies about ways of assessing payment discipline of potential business partner. In these studies we can find some recommended indicators for assessing payment discipline. There are some quantitative and some qualitative indicators. We can find these indicators in domestic and foreign literature. Many studies arises abroad and the results do not have to be applicable in the condition of emerging markets. Based on these researches we focused on the most recurring indicators and tried to prove the statement that these indicators are really statistically significant and have impact on payment discipline based on our data.

Based on these data we tried to create rating model to measure business partner creditworthiness. Creating own rating models to assess the creditworthiness of potential clients (trade credit claimants) is common for larger foreign companies. Trade receivable that is not paid properly and on time is common not only in larger companies abroad. Unpaid receivable represents a burden on the liquidity of the company in general. It can be cased that at the end the company that provided trade credit will not be able to pay its own commitments. Based on research results main problem why the company does not pay properly and on time is a liquidity problem. Proper early prediction of the financial health of potential client can significantly increase opportunity of timely payment. Creation own rating model is not as difficult as many companies think and the advantage of it is really big. After obtaining the necessary data it 
will be possible to evaluate the real development of the financial discipline of enterprises in the selected sector and its conformity with predicted.

In the future when we gain data from future financial statements it will be possible to predict its further development, taking into account already for a longer time period. In this case, we considered using a different method than the cohort method. Its main disadvantage is that it takes into account only the status at the beginning and the end of the period. In our case, we considered only two periods, so we did not have to deal with this. In the case of research into the future within a longer period of time, we are inclined to the use of duration method or Aalen Johansen estimate.

Wherever possible, we propose that companies incorporate not only quantitative but also qualitative indicators into the rating model. It was not possible due to the sample size. As part of the further research, we are planning to look at the existence of a non-linear dependence that could better describe the relationship between the selected indicators. The results of this research can be further exploited in creating an econometric liquidity management model.

Despite the fact that providing trade credits has become increasingly risky, mainly in recent years, we can see that payment discipline is not expected to deteriorate significantly. Rather, the problem is that businesses are not prudent in providing trade credits to potential business partners. If they paid enough attention to assessing their financial stability, they would not face the problem of unpaid invoices so often. Because the probability of transition between rating groups is not as high as the likelihood that the business partner will have the same rating level. Thus, if the company initially rated its potential business partner correctly, the risk of secondary insolvency would be considerably reduced.

\section{ACKNOWLEDGMENT}

The research leading to these results has received funding from the project titled "Creation of new paradigms of financial management at the threshold of the 21st century in conditions of the Slovak Republic" in the frame of the program of Slovak Scientific Grant Agency VEGA under the grant agreement number VEGA 1/0428/17.

\section{REFERENCES}

Abdou, H.A., Tsafack, M.D.D., Ntim, C.G. \& Baker, R.D. (2016). Predicting creditworthiness in retail banking with limited scoring data. Knowledge-based Systems, 25(3), 89-103. doi:10.1016/j.knosys.2016.03.023.

Act no. 7/2005 Coll. on bankruptcy and restructuring.

Balcerzak, A.P., Kliestik, T., Streimikiene, D., \& Smrcka, L. (2017). Non-Parametric Approach to Measuring the Efficiency of Banking Sectors in European Union Countries. Acta Polytechnica Hungarica, 14(7), 51-70.

Bracinikova, V. \& Matusinska, K. (2017). Marketing mix of financial services from the customers perspective. Forum Scientiae Oeconomia, 5(4), 35-48.

Business Alliance of Slovakia. (2019). Business Environment Index. Retrieved from https://www.alianciapas.sk/2019/04/09/ani-po-osmich-rokoch-sa-nezastavil-prepad-hodnoteniapodnikatelskeho-prostredia/

Cipovova, E., \& Belas, J. (2012). Assessment of Credit Risk Approaches in Relation with Competitiveness Increase of the Banking Sector. Journal of Competitiveness, 4(2), 69-84. doi: 10.7441/joc.2012.02.05

Cohen, J. (2003). Applied multiple regression/ correlation analysis for the behavioral science. Lawrence Erlbaum Associates: New York.

Culkova, K., Csikosova, A. \& Janoskova, M. (2015). Development of Risk Payment Index in Slovakia Comparing with Chosen EU Countries. Polish Journal of Management Studies, 12, 37-47.

Cygler, J., \& Sroka, W. (2017). Coopetition Disadvantages: the Case of the High Tech Companies. Inzinerine Ekonomika-Engineering Economics, 28(5), 494-504. 
Gorczynska, M. (2011). Accounts Receivable Turnover Ratio. The Purpose of Analysis in Terms of Credit Policy Management. 8th International Scientific Conference on Financial Management of Firms and Financial Institutions, Ostrava, Czech Republic.

Grinstead, CH. M., \& Snell, J. L. (1997). Introduction to Probability. American Mathematical Soc., 5(2), 464-466.

Grubbs, F. (1950). Sample criteria for testing outlying observations. Annals of Mathematical Statistics, 21(1), 5-8. doi: $10.1214 /$ aoms/1177729885.

Chajdiak, J., Rublikova, E., \& Gudaba, M. (1997). Statisticke metody v praxi. Statis: Bratislava.

Intrum Justitia. (2019). European Payment Index Report. Retrieved from https://www.intrum.com/press/publications/european-payment-report-2017/

Kestens, K., Van Cauwenberge, P., \& Vander Bauwhede, H. (2012). Trade Credit and Company Performance during the 2008 Financial Crisis. Accounting and Finance, 52, 1125-1151. doi:10.1111/j.1467-629X.2011.00452.x

Kliestik, T., Misankova, M., Valaskova, K., \& Svabova, L. (2018). Bankruptcy Prevention: New Effort to Reflect on Legal and Social Changes. Science and Engineering Ethics, 24(2), 791-803.

Kliestikova J., Misankova M., \& Kliestik T. (2017). Bankruptcy in Slovakia: international comparison of the creditor's position. Oeconomia Copernicana, 8(2), 221-237.

Kljucnikov, A., Kozubikova, L., \& Sopkova, G. (2017). The Payment Discipline of Small and Medium-sized Enterprises. Journal of Competitiveness, 9(2), 45-61. doi: 10.7441/joc.2017.02.04

Kollar, B., Kramarova, K., \& Valaskova, K. (2015). The Financial Distress Analysis of the Stated-Own Company by Applying Chosen Default Prediction Models in Condition of Slovakia. 3rd International Conference on Economics and Social Science (ICESS 2015), Paris, France.

Kozubikova, L., Homolka, L., \& Kristalas, D. (2017). The Effect of Business Environment and Entrepreneurs' Gender on Perception of Financial Risk in The SMEs Sector. Journal of Competitiveness, 9(1), 36-50. doi: 10.7441/joc.2017.01.03

Kralovic, J., \& Vlachynsky, K. (2006). Financing management. Bratislava: Edicia Ekonomia.

Kristofik, P. (1988). Manazment pohladavok - zakladna sucast riadenia obezneho majetku. Uctovnictvo Auditorstvo Danounictvo, 10.

Levy, H., \& Sarnat, M. (1988). Principles of Financial Management. Englewood Cliffs: PRENTICE HALL.

Michalski, G. (2013) Accounts Receivable levels in Relation to Risk Sensitivity in Manufacturing Firms in V4 Countries: 2003 2012 data testimony. 9th International Conference on Financial Management of Firms and Financial Institutions, Ostrava, Czech Republic.

Moravcikova, D., Krizanova, A., Kliestikova, J., \& Rypakova, M. (2017). Green marketing as the source of the competitive advantage of the business. Sustainability, 9(12), art.no. 2218.

Nica, E., \& Catalina-Oana, M. (2017). Are Increasing Student Loan Debt Levels Burdening Graduates?. Journal of SelfGovernance and Management Economics, 5(2), 68-74.

Nipun, A., Kwan, P., \& Paul, D. (2018).Merger and Acquisition Pricing Using Agent-Based Modelling. Economics, Management, and Financial Markets, 13(1), 84-99.

Olah, J., Zeman, Z., Balogh, I. \& Popp, J. (2018). Future challenges and areas of development for supply chain management. Log forum, 14(1), 127-138.

Paul, S. Y., \& Devi, S. (2012). Impact of Late Payment on Firms Profitability: Empirical Evidence from Malaysia. Pacific-Basin Finance Journal, 20, 777-792. doi:10.1016/j.pacfin.2012.03.004

Rimarcik, M. (2007). Statisticke metody pre prax. Vydane vlastnym nakladom.

Sadaf, R., Olah, J., Popp, J., \& Mate, D. (2018). An investigation of the influence of the worldwide governance and competitiveness on accounting fraud cases: A cross-country perspective. Sustainability, 10, ar. no: 588.

Salek, J. (2005). Account Receivable Management. New Jersey: John Wiley and Sons. 
Seneta, E. (1996). Markov and the Birth of Chain Dependence Theory. International Statistical Review / Revue Internationale de Statistique, 64(3), 255-257. doi: 10.2307/1403785.

Soucek, J., \& Kubickova, D. (2011). Management of Receivables in Czech Firms. International Conference on Current Issues in Management of Business and Society Development, Riga, Latvia.

Spahn, P. (2017). Central Bank Support for Government Debt in a Currency Union. Journal of Self-Governance and Management Economics, 5(4), 7-34.

Svabova, L., \& Durica, M. (2016). Correlation analysis of predictors used in bankruptcy prediction models in Slovakia. Ekonomicko-manazerske spektrum, 10(1), 2-11.

Valaskova, K., \& Gregova, E. (2017). Modelling of costs of capital in Slovak enterprises. Ekonomicko-manazerske spektrum, 11(2), 76-89.

Vojtovic, S. (2016). The Impact of the Structural Funds on Competitiveness of Small and Medium-Sized Enterprises. Journal of Competitiveness, 8(4), 30-45.

Voznakova, I. (2004). Efektivni rizeni pobladavek. Praha: Grada Publishing.

Weissova, I., Kollar, B., \& Siekelova, A. (2015) Rating as a useful tool for credit risk measurement. Procedia - Economics and finance, 26, 278-285. doi: 10.1016/S2212-5671(15)00853-9.

Weissova, I., \& Misankova, M. (2015). Problem with double accounting for goodwill and importance of market capitalization statement in this area. Financial management of firms and financial institutions : 10th international scientific conference, Ostrava, Czech Republic.

Weissova, I., \& Gregova, E. (2016). The role of selected variables in the issue of credit risk of company. ISSGBM international conference on information and business management (ISSGBM-IB 2016), Hong Kong.

Wells, R. (2004). Global Credit Management: An executive summary. Chichester: John Wiley and Sons. doi: 10.1002/9781118673300. 